\title{
FEEDING NON-PREFERENCE OF THE CORN LEAF APHID Rhopalosiphum maidis (Fitch, 1856) (Hemiptera: Aphididae) TO CORN PLANTS (Zea mays L.) TREATED WITHSILICON
}

\author{
Não-preferência do pulgão-da-folha Rhopalosiphum maidis (Fitch, 1856) (Hemiptera: Aphididae) \\ para plantas de milho (Zea mays L.) tratadas com silício
}

\author{
Jair Campos Moraes ${ }^{1}$, Márcio Marcos Goussain ${ }^{2}$, Geraldo Andrade Carvalho ${ }^{3}$, Rosane Rodrigues Costa ${ }^{4}$
}

\begin{abstract}
A tactic for control to corn leaf Rhopalosiphum maidis (Fitch, 1856) would be the use of resistant materials, but, for not being a key pest of the crop, there are not yet corn genotypes availables with those characteristics. So, it was aimed in this work to evaluate the effect of silicon on the aphid's development on corn plants. Preference tests with leaves detached from the plants and on corn plants were accomplished. Its was found that the treatments where silicon was applied to the soil plus a foliar sprayed fertilization or through two foliar applications were the ones which contained a lower number of aphids, increasing the resistance of leaves and making the feeding of those insects difficult. In general, the results showed that silicon affected the leaf aphid's preference.

Index terms: Insecta, resistance, IPM.

\section{RESUMO}

Uma tática para o controle do pulgão-do-milho Rhopalosiphum maids (Fitch, 1856) seria a utilização de materiais resistentes, porém, por não se tratar de uma praga-chave da cultura, não há, ainda, disponibilidade de genótipos de milho com essas características. Assim com o presente trabalho objetivou-se avaliar o efeito do silício na preferência do pulgão-da-folha em plantas de milho. Os tratamentos consistiram na aplicação de silício via solo e/ou foliar e testemunha. Foram realizados testes de não-preferência com folhas destacadas e diretamente em plantas de milho. Verificou-se que os tratamentos nos quais o silício foi aplicado via solo mais uma adubação foliar, ou mediante duas aplicações foliares, foram os que apresentaram menor número de pulgões, aumentando a resistência das folhas e dificultando a alimentação desses insetos. De modo geral, o silício afetou a preferência do pulgão-da-folha.
\end{abstract}

Termos para indexação: Insecta, resistência, MIP.

(Recebido para publicação em 3 de agosto de 2004 e aprovado em 22 de abril de 2005)

\section{INTRODUCTION}

Silicon is the second most abundant element, composing about $27 \%$ of the Earth's crust mass and is considered as the most important secondary mineral in the formation of soils. It is absorbed by plants as silicic acid $\left(\mathrm{SiO}_{2} \cdot \mathrm{nH}_{2} \mathrm{O}\right)$. Once absorbed, it is transported via xylem to all parts of the plant and deposited as amorphous or opalshaped $\mathrm{SiO}_{2} \cdot \mathrm{nH}_{2} \mathrm{O}$ (JONES \& HANDRECK, 1967). Once deposited, the silicon becomes immobile (ASTON \& JONES, 1976). The accumulation and polymerization of silicon in the epidermal cells as amorphous silica, immediately below the cuticle, forms a mechanical barrier called "double layer silicon-cuticle", which helps to maintain the leaves erect, reducing the transpiration and protecting the plants against insects and fungal attacks (YOSHIDA, 1975). Nevertheless, the barrier created by the silicon in the epidermal cells is not the only defense mechanism against attacks of insects or fungal penetration. Induced resistance has also been reported as a mechanism against fungi
(CHÉRIF et al., 1992a, b; SAMUELS et al., 1991). The response mechanism of plant to attack by sucking insects has some similarities to those folloing attack by pathogens (DREYER \& CAMPBELL, 1987).

The population reduction of Metopolophium dirhodum (Walker, 1848) (Hemiptera: Aphididae) and Sitobion avenae (Fabricius, 1794) (Hemiptera: Aphididae) on wheat leaves, after leaf application of silicon $(1 \%$ $\mathrm{Na}_{2} \mathrm{SiO}_{2}$ ), is not only the result of leaf rigidity increasing, but is also due to a higher solubility of silicon in the leaf cell (HANISCH, 1980).

Rice seedlings treated with silicon resulted in fewer nymphs of Sogatella furcifera (Horváth, 1899) (Hemiptera: Delphacidae) reaching adulthood and a higher proportion of males (KIN \& HEINRICHS, 1982). Silicon added as nutritive solution reduced feeding, development, longevity and fecundity of this insect (SALIM \& SAXENA, 1992). Silicon application to sorghum also caused reduction of feeding and reproduction of Schizaphis graminum (Rondani, 1852) (Hemiptera: Aphididae) (CARVALHO et al., 1999).

\footnotetext{
${ }^{1}$ Professor do Departamento de Entomologia, Universidade Federal de Lavras - Caixa Postal 3037 - 37200-000 - Lavras, MG - jcmoraes@ufla.br ${ }^{2}$ Engenheiro Agrônomo, Doutorando em Entomologia/UFLA.

${ }^{3}$ Professor do Departamento de Entomologia/UFLA.
} 
The objective of this study was to evaluate the effect of silicon application to corn plants on the feeding preference of the corn leaf aphid Rhopalosiphum maidis (Fitch, 1856).

\section{MATERIALSANDMETHODS}

This work was carried out in a greenhouse of the Departamento de Entomologia, Universidade Federal de Lavras (UFLA), Brazil. Three seeds of corn, cv Cargill C444 , were sown in a $4 \mathrm{~kg}$ capacity plastic pots filled with a substrate composed of a mixture of sand, soil and bovine manure in equal proportion. After emergence, only one plant per pot was retained. The moisture in the pots was maintained by daily irrigation and plants received urea at a rate of $100 \mathrm{mg} / \mathrm{kg}$ of soil, 10, 20 and 30 days after emergence.

Plant groups (mother stock) comprising five treatments were kept in a greenhouse to provide plants or leaves for the experiments. The treatments used were: $\mathrm{T}_{1}=$ Untreated (no silicon); $\mathrm{T}_{2}=16 \mathrm{~mL}$ of a sodium silicate solution, applied to the soil, in two applications of $8 \mathrm{~mL}$ of sodium silicate solution $+92 \mathrm{~mL} \mathrm{H}_{2} \mathrm{O}$ each, at five and 20 days after emergence of plants; $\mathrm{T}_{3}=$ similar to $\mathrm{T}_{2}$, plus one foliar spray of $0.5 \% \mathrm{SiO}_{2}$, using an average volume of 28 $\mathrm{mL}$ of the solution per plant, applied 30 days after emergence; $\mathrm{T}_{4}=$ two foliar sprays of $0.5 \% \mathrm{SiO}_{2}$ using an average volume of $28 \mathrm{~mL}$ per plant, applied at 15 and 30 days after emergence; and $\mathrm{T}_{5}=$ one foliar spray of $0.5 \%$ $\mathrm{SiO}_{2}$, using an average volume of $28 \mathrm{~mL}$ of solution per plant, applied 30 days after emergence. In all treatments, a Merck $^{\circledR}$ sodium silicate solution (concentration of 25 to $28 \% \mathrm{SiO}_{2}$ ) was used.

The following evaluations were performed: a) preference choice test using plant-detached leaves in the laboratory; b) preference choice test on plants under greenhouse conditions; c) silicon content determination.

\section{a) Free choice test using plant-detached leaves in the laboratory.}

Detached leaves were obtained from different plants of the mother stock. The five treatments were arranged in a randomized blocks design, with 12 replicates. A $19 \mathrm{~cm}$ diameter Petri dish, containing five sections of $0.8 \mathrm{~cm}^{2}$ corn leaf, per plot and per treatment. Leaf sections were equidistantly distributed within the plate, creating an arena, free choice test. Each leaf section was cut from the plant with the central nervure. The bottom part of the nervure was wrapped with cotton and placed into a $5 \mathrm{~mL}$ capacity cylindrical vial containing a $\mathrm{N}$-benziladenine solution at a $10^{-6} \mathrm{M}$ concentration, in order to maintain leaf turgidity for as long as possible. Twenty wingless adult aphids were released in the center of the arena, and the Petri dish was then sealed with PVC film. The bioassays were carried out under controlled conditions at $23 \pm 2^{\circ} \mathrm{C}, 70 \pm 10 \% \mathrm{RH}$ and 12 h photophase.

Evaluations were made daily by recording the presence of adult aphids on the leaf sections until 96 hours after infestation. The nymphs were removed after each evaluation.

\section{b) Pair choice test on plants under greenhouse conditions.}

Plants were also obtained from the mother stock. The test was conducted in the greenhouse using a completely randomized experimental design, with five treatments and six replicates under a subdivided plot scheme where the silicon treatments and control were allocated to the plots and the evaluation times were allocated to sub-plots. Each plot consisted of a round plastic clip cage of $5.4 \mathrm{~cm}$ diameter and $1.2 \mathrm{~cm}$ high (Figure 1). Inside the clip cage two leaves from different treatments were fixed. The pots were paired always facing a treatment with silicon with the untreated. Ten adult aphids were released inside the clip cage. The abaxial blade of the eighth totally extended leaf was used, and the cages were placed in apical third of the blade.

Evaluations were performed 24, 48 and 72 hours after releasing the aphids, by counting the number of individuals present in each treatment. Aphids not on leaves at the moment of evaluations were not recorded.

\section{c) Silicon content determination.}

Plants leaves were also obtained from the mother stock. The test was conducted in the greenhouse using a completely randomized experimental design, with five treatments and six replicates. The silicon content determination was done on the ninth fully extended leaf, 40 days after emergence according to the methodology described by Elliott \& Snyder (1991).

Data were subjected to ANOVA and those concerning the number of aphids were transformed to $\sqrt{x+0.5}$, prior analysis. The means were compared by the Scott \& Knott grouping test (Pd"0.05) (SCOTT \& KNOTT, 1974). 


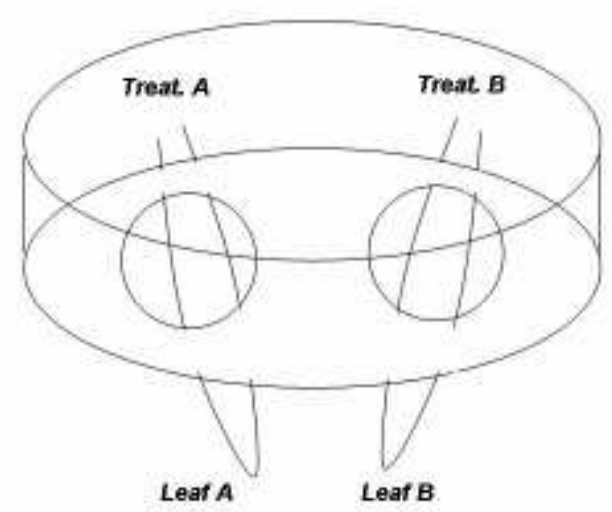

FIGURE 1 - Diagram showing the micro-cage used for choice test with living plants.

\section{RESULTS}

\section{a) Free choice test using plant-detached leaves in the laboratory.}

The mean numbers of aphids present in leaf sections from silicon treated plants through soil and foliar (T3), and from two foliar applications (T4) were similar (1.8 \pm 0.3 and $2.4 \pm 0.3$ respectively), and significantly lower than the other treatments, 96 hours after exposure (Table 1). To detect any kind of resistance to aphids a minimum of 72 hours test has been recommended (CRUZ et al., 1998).

\section{b) Pair choice test on plants under greenhouse conditions.}

Equal numbers of aphids were found on leaves treated with one foliar silicon spray and on untreated leaves after 24 and 48 hours. After 72 hours exposure, the aphids preferred to settle on untreated leaves avoiding silicon treated plants $(4.0 \pm 0.9$ and $1.2 \pm 0.5$ aphids, respectively). Aphids choosing untreated leaves remained on them during the evaluated period meanwhile those initially choosing treated plants tended to abandon them after 48 hours exposure (Table 2, pair A).

The aphid preference was not affected during 72 hours test when silicon was applied only through the soil and aphids were found equally on both plants, treated and untreated (Table 2, pair B).

Silicon applications through soil and one foliar spray affected significantly aphid preference already at 48 hours, remaining the difference at 72 hours after exposure. Untreated leaves had $4.0 \pm 0.9$ aphids against $1.3 \pm 0.3$ aphids found in the treated leaves after 72 hours exposure (Table 2, pair C).

Two foliar sprays (15 and 30 days after plant emergence) showed a lower number of aphids on treated leaves compared with untreated leaves at 24 hours exposure ( $2.6 \pm 0.3$ and $4.4 \pm 0.3$, respectively). The difference remained similar until the last evaluation at 72 hours (Table 2, pair D).

\section{c) Silicon content determination.}

Following the application of silicon via soil and/or leaf-spray, using a sodium silicate solution as the source of this element, the content of silicon in the leaves of the corn plants was significantly increased (Table 3). Silicon applied via soil with an additional foliar spray, or as a single application via soil, were the treatments that promoted the highest content of $\mathrm{SiO}_{2}$ (2.6\% and $2.5 \%$, respectively) in leaves. The values for the treatments with one and two leaf-sprays were intermediate, with mean contents of $1.7 \%$ and $2.0 \%$ of $\mathrm{SiO} 2$, respectively. Nevertheless, these figures were still significantly different from the control. 
TABLE 1 - Mean number ( \pm standard error) of the corn leaf aphid R. maidis on detached leaf sections of corn plants 96 hours after release of adults.

\begin{tabular}{lc}
\hline \multicolumn{1}{c}{ Treatments } & Number of aphids* \\
\hline Untreated & $3.0 \pm 0.3 \mathrm{a}$ \\
Silicon via soil & $3.8 \pm 0.4 \mathrm{a}$ \\
Silicon via soil + one foliar spray & $1.8 \pm 0.3 \mathrm{~b}$ \\
Silicon two foliar sprays & $2.4 \pm 0.3 \mathrm{~b}$ \\
Silicon one foliar spray & $3.3 \pm 0.3 \mathrm{a}$ \\
\hline * Means followed by the same letter are not significantly different according to the Scott and Knott test (Pf 0.05$).$
\end{tabular}

TABLE 2 - Mean number ( \pm standard error) of the corn leaf aphid $R$. maidis on corn leaves after release of adults into micro-cage arenas under greenhouse conditions (Pair test).

\begin{tabular}{llccc}
\hline \multirow{2}{*}{ Treatments } & \multicolumn{3}{c}{ Time after release (h) } \\
\cline { 3 - 5 } & & $\mathbf{2 4}$ & $\mathbf{4 8}$ & $\mathbf{7 2}$ \\
\hline Pair A & Silicon one foliar spray & $3.7 \pm 0.7$ a A & $4.2 \pm 1.0$ a A & $1.2 \pm 0.5$ b B \\
& Untreated & $3.7 \pm 0.7$ a A & $5.1 \pm 1.1$ a A & $4.0 \pm 0.9$ a A \\
\hline Pair B & Silicon via soil & $3.7 \pm 0.7$ a A & $4.0 \pm 0.6$ a A & $3.0 \pm 0.6$ a A \\
& Untreated & $4.7 \pm 0.8$ a A & $2.5 \pm 0.8$ a A & $2.3 \pm 1.1$ a A \\
\hline Pair C & Silicon via soil + one foliar spray & $4.5 \pm 0.7$ a A & $2.3 \pm 0.5$ b B & $1.3 \pm 0.3$ b B \\
& Untreated & $3.7 \pm 0.6$ a A & $5.1 \pm 1.1$ a A & $4.0 \pm 0.9$ a A \\
\hline Pair D & Silicon two foliar sprays & & & \\
& Untreated & $2.6 \pm 0.3 \mathrm{~b} \mathrm{~A}$ & $2.6 \pm 0.3 \mathrm{~b} \mathrm{~A}$ & $2.6 \pm 0.3 \mathrm{~b} \mathrm{~A}$ \\
& & $4.4 \pm 0.3$ a A & $4.4 \pm 0.3$ a A & $4.4 \pm 0.3$ a A \\
\hline
\end{tabular}

* Means followed by the same small letter in the column and capital letter in the line, are not significantly different according to Scott and Knott test (P£ 0.05).

Ciênc. agrotec., Lavras, v. 29, n. 4, p. 761-766, jul./ago., 2005 
TABLE 3 - Percent silicon content (mean \pm standard error) in silicon-treated and untreated leaves of corn plants evaluated 40 days after emergence of plants.

\begin{tabular}{ll}
\hline \multicolumn{1}{c}{ Treatments } & $\mathrm{SiO}_{2}$ content $(\%) *$ \\
\hline Untreated & $1.0 \pm 0.07 \mathrm{c}$ \\
Silicon via soil & $2.5 \pm 0.12 \mathrm{a}$ \\
Silicon via soil + one foliar spray & $2.6 \pm 0.16 \mathrm{a}$ \\
Silicon two foliar sprays & $2.0 \pm 0.29 \mathrm{~b}$ \\
Silicon one foliar spray & $1.7 \pm 0.12 \mathrm{~b}$ \\
\hline
\end{tabular}

* Means followed by the same letter are not significantly different according to the Scott and Knott test (P£ 0.05).

\section{DISCUSSION}

The highest level of induced resistance to aphids was observed on plants that had received one application via soil and an additional foliar spray. Two foliar sprays of silicon did not significantly differ from this treatment. Silicon applications exclusively through the soil did not appear to affect aphid preference during 96 hours testing. Foliar sprays shown to be more efficient to repel aphids and two foliar sprays shown to affect aphid preference faster than other treatments. Other authors have reported similar results using other species of insects and host plants. Almost twice as many aphids of the greenbug Schizaphis graminum were found on untreated sorghum plants compared with silicon treated plants in a preference bioassay during 64 hours testing (CARVALHO et al., 1999). They concluded that the lower preference of aphids for silicon-treated leaves occurred due to a mechanical barrier sustained by the arrangement of this element in the cell walls. Evidence showed that the deposition and the increased silicon solubility within the leaves were the inducers of resistance in wheat plants to two important aphids, M. dirhodum and S. avenae, after a foliar application of this element as a $1 \% \mathrm{Na}_{2} \mathrm{Si}_{2}$ solution (HANISCH, 1980).

These results showed silicon applications did promote an increase of its content in the leaves of corn plants. Concerning the degree of resistance to aphids, however, its distribution to all plant parts is sometimes either equally or more important than its content. This was confirmed in the plants that received only one application via soil, which even though presenting a higher $\mathrm{SiO}_{2}$ content than the control, were equally preferred by the aphids (Table 2, pair B and Table 3).

Results have shown that the application of silicon contributed to an increase in the induced-nonpreference of the corn plants to the aphid $R$. maidis, possibly by forming a mechanical barrier (CHÉRIF et al., 1992a, b; SAMUELS et al., 1991) and/or stimulating the plants to produce defense chemical substances that impaired the feeding non-preference of the insects. However, these questions should be further and more investigated, mainly those related to silicon distribution within the plant or those related to induction of secondary defence compound synthesis and under a no choice test.

\section{CONCLUSION}

The application of silicon contributed to an increase in the resistance of the corn plants to the corn leaf aphid $R$. maidis, mainly when applied to the soil plus one foliar spray or two foliar sprays.

\section{REFERENCES}

ASTON, M. J.; JONES, M. M. Study of the transpirational surfaces of Avena sterilis L. var. Algerian leaves using monosilicic acid as a tracer for water movement. Planta, Berlin, v. 130, n. 2, p. 121-129, 1976. 
CARVALHO, S. P.; MORAES, J. C.; CARVALHO, J. G. Efeito do silício na resistência do sorgo (Sorghum bicolor) ao pulgão-verde Schizaphis graminum (Rond.) (Homoptera: Aphididae). Anais da Sociedade Entomológica do Brasil, Piracicaba, v. 28, n. 4, p. 505-510, 1999.

CHÉRIF, M.; BENHAMOU, N.; MENZIES, J. G.; BÉLANGER, R. R. Silicon induced resistance in cucumber plants against Pythium ultimum. Physiological and Molecular Plant Pathology, London, v. 41, p. 411-425, 1992a.

CHÉRIF, M.; MENZIES, J. G.; BENHAMOU, N.; BÉLANGER, R. R. Studies of silicon distribution in wounded and Pythium ultimum infected cucumber plants. Physiological and Molecular Plant Pathology, London, v. 41,p. 371-385, 1992 b.

CRUZ, I.; VENDRAMIN, J. D.; OLIVEIRA, A. C. Determinação do período de avaliação de não-preferência de sorgo ao pulgão-verde, Schizaphis graminum (Rond.) (Homoptera: Aphididae). Anais da Sociedade Entomológica do Brasil, Piracicaba, v. 27, p. 299-302, 1998.

DREYER, D. L.; CAMPBELL, B. C. Chemical basis of hostplant resistance to aphids. Plant, Cell and Environment, Oxford, v. 10, p. 353-361, 1987.

ELLIOTT, C. L.; SNYDER, G. H. Autoclave-induced digestion for the colorimetric determination of silicon in rice straw. Journal Agricultural and Food Chemistry, Easton, v. 39, p. 1118-1119, 1991.
HANISCH, H. C. Zun einfluss der stickstoffdungung und vorbeugender spritzung von natronwasser glas zu weizenpflanzem auf deren widerstandsfahigkeit gegen getreideblattlause. Kali-Driefe, Berlin, v. 15, p. 287-296, 1980.

JONES, L. H. P.; HANDRECK, K. A. Silica in soils, plants, and animals. Advances in Agronomy, San Diego, v. 19, p. 107-149, 1967.

KIN, H. S.; HEINRICHS, E. A. Effects of silica level on whitebacked planthopper. International Rice Research Newsletter, Manila, v. 7, p. 17, 1982.

SALIM, M.; SAXENA, R. C. Iron, silica and aluminium stresses and varietal resistance in rice: effects on whitebacked planthopper. Crop Science, Madison, v. 32, p. 212-219, 1992.

SAMUELS, A. L.; GLASS, A. D. M.; EHRET, D. L.; MENZIES, J. G. Mobility and deposition of silicon in cucumber plants. Plant, Cell and Environment, Oxford, v. 14,p. 485-492, 1991.

SCOTT, A. J.; KNOTT, M. A. A cluster analysis method for grouping means in the analysis of variance. Biometrics, Washington, v. 30, p. 507-512, 1974.

YOSHIDA, S. The physiology of silicon in rice. Taipei: Food and Fertilization Technology Center, 1975. (Technical bulletin, 25). 